http://dx.doi.org/10.4314/jae.v18i2.13

\title{
Knowledge and Roles of Non Governmental Organizations (NGOs) in Climate Change Mitigation and Adaptation in Anambra State
}

\author{
Iwuchukwu J.C, Nwankwo O.J and Ogbonna, O.I \\ Department of Agricultural Extension, \\ University of Nigeria Nsukka, Enugu state, Nigeria. \\ E-mail julieiwuchukwu@yahoo.com (08063276459)
}

\section{Abstract}

The study ascertained knowledge and perceived roles of state based-Non Governmental Organizations (NGOs) in climate change mitigation and adaptation in Anambra State, Nigeria. Multistage random sampling technique was employed to select thirty five respondents from 4 local government areas and 7 NGOs in the state while data were collected with questionnaire. Percentage and mean scores were used in analyzing the data. Results revealed that greater proportion (60\%) of NGO members were not aware of climate change while about $63 \%$ indicated that issues on climate change have not been included in their programme. They perceived major causes of climate change as over industrialization $(M=2.77)$ and use of automobiles $(M=2.74)$ while land degradation and over flooding ( $M=2.77$ each) were major effects of climate change. Proper land use and management $(M=2.89)$ and reforestation/ $(M=2.83)$ were mitigation measures while minimum tillage $(M=2.74)$ and use of resistant varieties $(M=)$ were adaptive measures to climate change as perceived by them. They further perceived creation of awareness and sensitization of rural people/farmers about climate change (77.1\%each) and helping government in enforcement of policies and laws that will help to mitigate climate change (57.1\%) as roles they can play in climate change mitigation and adaptation. They did not perceive any major problem that can mar their contributions to climate change issue. The study emphasized on the need for private sector especially NGOs investment and participation in global and sensitive issues like climate change. This will go a long way in discovering and disseminating quick and useful information on climate change and probably ultimate solution to it.

\section{Keywords Knowledge; roles; NGOs; climate change}

\section{Introduction}

Climate change can be defined as a statistically significant variation in weather that persist for an extended period typically decades or longer (Intergovernmental Panel on Climate Change (IPCC), 2007). It is made up of discrepancies in the occurrences and magnitude of sporadic weather events and concomitant rise in world mean surface temperature. Its effects include among others increasing temperatures, decreasing rainfall in the continental interiors, drought desert encroachment, melting ice, extreme weather, flood, sea level rise, sinking of islands, water scarcity health and agricultural problems (Odjiugo, 2009). 
Climate change is a global concern and studies show that many people are aware and knowledgeable of the phenomenon (Onyeme and Iwuchukwu, 2012; Okoro, 2012). Changes associated with it have the potential to alter ways in which people live their lives globally. These global changes not only threaten to deprive humans of their lands but also to end lives of living things that cannot adapt to the chaotic weather the world is experiencing (www.articlesbase.com/science-articles/climate-change-aglobal-challenge-a-global-concern-3133806.html). These challenges being posed possess the capacity to increase the already existing poverty situations across many countries of the world, affect more people generally thereby increasing the vulnerability of the poorer countries and groups (Egbule, 2012)

Thus there is need for mitigation and development of strategies that will help human beings to adapt to climate change. Mitigation refers to any strategy or action taken to remove the green house gases released into the atmosphere, or to reduce their amount. Mitigation may also be seen as implementing policies to reduce GHG emissions and enhance sinks

http://know.climateofconcern.org/index.php?option=com content\&task=article\&id=143. It is also efforts to adjust to ongoing and potential effects of climate change (Murthukumara, Anil and Vijul, 2008). Adaptation to climate change refers to adjustment in natural or human systems in response to actual or expected climatic stimuli or their effects, which moderates harm or exploits beneficial opportunities. This can occur in physical, ecological, and human systems. Adaptation and mitigation are therefore complementary to each other. For example, if mitigation measures are undertaken effectively, lesser will be the impacts to which we will need to adapt. Similarly, if adaptation measures (or the degree of preparedness) are strong, lesser might be the impacts associated with any given degree of climate change.

http://know.climateofconcern.org/index.php?option=com content\&task=article\&id=143

The characteristics and implications of climate change show that it is a multi-dimensional problem whose causes and effects are challenges to recent development initiatives. Hence the need for trans-disciplinary approaches towards its mitigation and adaptation. These may have risen the concern and interest of individuals, researchers, organisations especially non governmental organisations (NGOs) on this issue of global warming with the view of having balanced approach towards addressing climate change through short and long-term measures.

NGO is a legally constituted, voluntary association of individuals or groups that is neither a government agency nor profit enterprise. It is a private organisation that pursues activities to relieve suffering, promote the interests of the poor, protect the environment, provide basic social services, and/or understand community development (World Bank, 2001). Some NGOs have participated in climate change issue. For examples Chevron that participated in the Carbon Sequestration Leadership Forum, an international climate change initiative focused on development of improved, cost-effective technologies for the separation and capturing of carbon dioxide (www.chevron.com/global issues/climatechange/?utm-campaign=Africa:-corporate-iee). The Climate Action Network (CAN) a worldwide network of over 430 Non-Governmental Organizations (NGOs) working to promote government and individual action to limit human-induced climate 
change to ecologically sustainable levels www.eeaClimate Action Network Europe (CANE) among others.

In Nigeria, and specifically in Anambra State quite a number of NGOs exist but at different levels and orientations. Some are community, city, state nationally and internationally based. Also, they have acquired different orientations focusing on service, charity, participation and empowerment (Igwe, 2006; PAMNET, 2008). It is possible that they are experiencing and participating in climate change issue hence the need to investigate on their knowledge/ perceptions on climate change and their roles toward its mitigation and adaptation. The study specifically ascertained NGOs awareness, perceived causes, effects, mitigation and adaptation measures to climate change, perceived roles as well as barriers to performance of these roles in clmate change mitigation and adaptation.

\section{Methodology}

\section{Population and sample}

The study was carried out in Anambra state, Nigeria. Members of NGO in the state constituted the population for the study. Multistage sampling procedure was employed in the selection of the respondents. The first stage involved purposive selection of four (Awka South, Awka North, Onitsha South and Onitsha North) local government areas (LGAs)) out of the twenty-one LGAs in the State. This was due to pronounced existence and activities of NGOs in these areas. In the second stage, fifteen percent of NGOs were proportionately selected from each LGA. Thus, three and two NGOs were selected from Awka South and Onitsha North respectively while an NGO each was selected from Awka North and Onitsha South. In the third stage, five members( officials and active members) of NGOs were purposively selected from each NGO giving a total of thirty five respondents for the study.

\section{Data collection}

Data were collected with questionnaire. The instrument contained relevant questions based on the specific objectives of the study. Data were collected on NGOs awareness and out reach programme on climate change. Also, data on causes, effects, mitigation and adaptation measures to climate change were collected using 3 point Thurstone type scale with response options as 'to a great extent' $=3$, 'to a little extent' $=2$ and ' to no extent' $=1$ with a mean of 2 . Response with a mean score equal or greater than 2 was regarded as a cause of climate change while any one less than 2.0 was regarded otherwise. This decision was also applied on effects, mitigation and adaptation measures to climate change. Respondents were also requested to indicate roles their NGOs can play in climate change mitigation and adaptation. Also data on perceived barriers to performance of these roles were collected on a 3-point Thurstone type scale of 'to a great extent' $=3$, 'to a little extent' $=2$ and 'to no extent' $=1$ with a mean of 2 .. Mean scores equal or greater than 2 were regarded as major barriers while those less than 2.0 were regarded as minor barriers to effective performance of NGOs roles in climate change mitigation and adaptation. 


\section{Results and Discussion}

\section{Awareness and out -reach programme of NGOs on climate change}

Data in Table 1 shows that greater proportions (60\%) of the respondents were aware of climate change while $40 \%$ were not aware of it. About $63 \%$ of these respondents indicated that their organisations had not included climate change in their programme while $37 \%$ indicated that they had included. Greater proportion (51.4\%) of the respondents revealed that their organisations had not reached farmers/rural people with information on climate change while the remaining percentage $(48.6 \%)$ revealed that they had reached farmers/rural people with the information (Table 1). This means that most of the NGO's are yet to incorporate climate change into their programme which may be facilitated by the awareness of climate change by members

Table1: Percentage distribution of NGOs activities on climate change Climate change issues Percentage $(n=35)$

\section{Awareness}

Aware

Not aware

60.0

Inclusion of climate change in programme

Included

Not included

Out reach with farmers /rural people on climate

\section{change}

Outreach

No outreach

\section{Causes of climate change}

Entries in Table 2 show that the respondents perceived all the factors in the table as causes of climate change. These factors include deforestation/desertification $(M=2.86)$, improper waste recycling and disposal $(M=2.80)$, over industrialization $(M=2.77)$, carbon dioxides emission from transporting vehicles $(M=2.74)$, carbon dioxide emission from burning of fuel and power plants $(M=2.71)$, excessive use of chemicals such as fertilizers and agro-chemicals $(\mathrm{M}=2.66)$, methane gas from animal manures, crop plants etc $(M=2.43)$ and solar radiation $(M=2.29)$. Actually, these factors cause climate change implying that these respondents are knowledgeable about causes of climate change. Their knowledge about causes of climate change is advantageous since low level of knowledge retard the adaptation potential of community and make them more vulnerable to climate change. 
Table2: Respondents perceived causes of climate change

\begin{tabular}{lcc}
\hline Causes & Mean & $\begin{array}{c}\text { Standard } \\
\text { Deviation }\end{array}$ \\
\hline Deforestation/desertification & 2.86 & 0.36 \\
Excessive use of chemicals such as fertilizers and & 2.66 & 0.48 \\
agro-chemicals & 2.77 & 0.43 \\
Over industrialization & 2.71 & 0.57 \\
Carbon monoxide emission from burning of fuel and & & 0.51 \\
power plants & 2.74 & 0.74 \\
Carbon monoxides emission from transporting & 2.43 & 0.71 \\
vehicles & 2.29 & 0.53 \\
Solar radiation & 2.80 &
\end{tabular}

\section{Effects of climate change}

Table 3 reveals that excessive land degradation, extreme weather condition and over flooding ( $M=2.77$ each) were mostly perceived by the respondents asnnnn effects of climate change. Other effects of climate change as perceived by the respondents were increase in environmental temperature $(\mathrm{M}=2.74)$ increase in pests and disease outbreak due to ecological imbalance $(M=2.51)$, extinction of important:t ecological species and excessive drought (dryness of the land) $(\mathrm{M}=2.49 \mathrm{each})$ and scarcity of water due to high rate of evaporation $(M=2.43)$. The findings corroborate the fact that global warming (climate change) is projected to have significant impact on conditions affecting agriculture, including temperature, carbon dioxide, glacial run-off, precipitation and the interaction of these elements (Fraser, 2008). Similarly, indirect effect of climate change on agriculture may include effects on pests and diseases and impacts of these on agricultural production. 
Table 3: Respondents perceived effects of climate change

\begin{tabular}{lcc}
\hline Effects & Mean & $\begin{array}{c}\text { Standard } \\
\text { Deviation }\end{array}$ \\
\hline Scarcity of water due to high rate of evaporation & 2.43 & 0.5 \\
Excessive drought (dryness of the land) & 2.49 & 0.51 \\
Increase in pests and disease outbreak due to & 2.51 & 0.66 \\
ecological imbalance & 2.77 & 0.43 \\
Excessive land degradation & 2.77 & 0.43 \\
Extreme weather condition & 2.77 & 0.43 \\
Over flooding & 2.74 & 0.51 \\
'Increase in environmental temperature & 2.49 & 0.61 \\
Extinction of important ecological species & 1.66 & 0.77 \\
Seasonal migration & &
\end{tabular}

\section{Perceived mitigation measures to climate change}

Data in Table 4 indicate that proper land use management $(M=2.89)$ was mostly perceived by the respondents as mitigation measure to climate change. Other mitigation measures to climate change as perceived by the respondents were reforestation and promotion of environmental management education ( $\mathrm{M}=2.83 \mathrm{each})$, proper waste disposal and management $(M=2.8)$, avoidance of bush burning $(M=2.74)$, promotion of awareness campaign on climate change $(M=2.71)$, improvement of urban planning $(M=2.54)$,population control $(M=2.26)$ and use of organic manure $(M=2.14)$.

It is a known fact that when land and the environment are properly managed through reforestation, proper drainage system and waste management, they will directly or indirectly combat climate change as mitigation helps to reduce the rate and magnitude of climate change (IPCC, 2001). However, Stem (2006) identified reducing demand for emission intensive goods and services, increasing efficiency gains, increasing use and development of low carbon technologies and reducing fossil fuel emissions as mitigation measures to climate change. 
Table 4: Respondents perceived mitigation measures to climate change

\begin{tabular}{lcc}
\hline Adaptive measures & Mean & Standard Deviation \\
\hline Proper land use management & 2.89 & 0.4 \\
Reforestation & 2.83 & 0.45 \\
Promoting environmental management education & 2.83 & 0.49 \\
Promoting awareness campaign on climate change & 2.71 & 0.46 \\
Proper waste disposal and management & 2.8 & 0.41 \\
Improve urban planning & 2.54 & 0.56 \\
Population control & 2.26 & 0.74 \\
Use of organic manure & 2.14 & 0.73 \\
Avoidance of bush burning & 2.74 & 0.51 \\
\hline
\end{tabular}

\section{Perceived adaptive measures to climate change}

All the factors in Table 5 were perceived by the respondents as adaptive measures to climate change. Prominent among them are planting of trees $(M=2.77)$, minimum tillage $(M=2.69)$, planting of early maturing crops $(M=2.6)$, planting of cover crops, use of resistant varieties/species of crops and animals and planting of cover crops ( $M=2.6 e a c h)$. Other adaptive measures as perceived by the respondents are early /prompt harvesting of crops to reduce incidence of pest and diseases $(M=2.43)$, terracing $(M=2.37)$, diversification of enterprise $(M=2.34)$, change in planting date, mulching to reduce water loss and increased frequency of weeding( $M=2.29)$. In line with this finding, Egbule (2013) reported that farmers change harvesting dates, increase number of weeding, practice minimum tillage as adaptation strategies to the negative impacts of climate change.

Table 5: Respondents perceived adaptive measures to climate change

\begin{tabular}{lcc}
\hline Adaptive measures & Mean & $\begin{array}{c}\text { Standard } \\
\text { Deviation }\end{array}$ \\
\hline Change in planting date & 2.29 & 0.57 \\
Mulching to reduce water loss & 2.29 & 0.62 \\
Planting of trees & 2.77 & 0.43 \\
Planting of early maturing crops & 2.6 & 0.50 \\
Increased frequency of weeding & 2.29 & 0.71 \\
Terracing (planting across the slope) & 2.37 & 0.73 \\
Planting of cover crops & 2.57 & 0.56 \\
Early / prompt harvesting of crops to reduce incidence of & 2.43 & 0.70 \\
pest and diseases & 2.34 & 0.64 \\
Diversification of enterprise & 2.57 & 0.56 \\
Use of resistant varieties / species of crops and animals & 2.57 & 0.56 \\
Irrigation & 2.69 & 0.53 \\
Minimum tillage & & \\
\hline
\end{tabular}

Roles NGOs can play in climate change mitigation and adaptation

Entries in Table 6 reveals that majority (77.1\%each) of the respondents indicated creating awareness and sensitizing the public about climate change as well as educating/advising 
the public on the effects of climate change as roles NGOs can play in climate change mitigation and adaptation. Also, greater proportion (57.1\%) of them indicated helping government in enforcement of law that will mitigate climate change as roles NGOs can play in climate change mitigation and adaptation. This finding tend to confirm the fact that NGOs provide a large part of educational services (Ibembe, 2007) while adapting easily to the specific political, economic and social context in a country.

Table 6: Perceived roles of NGOs in climate change mitigation and adaptation

\begin{tabular}{|c|c|c|}
\hline S/No & Perceived roles & $\begin{array}{l}\text { Percentage } \\
(\mathrm{n}=35)\end{array}$ \\
\hline 1 & $\begin{array}{l}\text { Creating awareness and sensitizing the public about climate } \\
\text { change }\end{array}$ & 77.1 \\
\hline 2 & Educating/advising the public on the effects of climate change. & 77.1 \\
\hline 3 & $\begin{array}{l}\text { Providing incentives and subsidies that will restrain them from } \\
\text { practices that cause climate change }\end{array}$ & 25.7 \\
\hline 4 & $\begin{array}{l}\text { Helping government in enforcement of law that will mitigate } \\
\text { climate change }\end{array}$ & 57.1 \\
\hline 5 & $\begin{array}{l}\text { Provision of incentives that will help them adapt to climate } \\
\text { change }\end{array}$ & 31.4 \\
\hline
\end{tabular}

Barriers to performance of NGOs roles in climate change mitigation and adaptation It can be inferred from Table 7 that there was no major barrier to the performance of NGOs roles in climate change mitigation and adaptation. Some of the minor barriers to performance of these roles by NGOs as perceived by the respondents were poor attitude of staff towards embracing new issue like climate change $(M=1.89)$, incompetence of staff to handle climate change issue $(M=1.83)$, climate change not within the NGO scope or area of interest and low man power in the organisation $(\mathrm{M}=1.80 \mathrm{each})$, reluctance of people to participate in NGO programme and inaccessibility of some areas where climate change information are needed ( $M=1.66$ each). In as much as there are no major challenges confronting NGOs in playing their role in climate change mitigation and adaptation, there is need to guard against the aforementioned minor challenges that may manifest as major challenges in future. It is also surprising that lack of fund/finance that used to be major problem of many organisations and development programmes in developing countries like Nigeria was not seen as such in performance of NGOs roles in climate chang e. This may be due to adequate funding by donors. 
Table7: Perceived barriers to NGOs roles on climate change mitigation and adaptation

\begin{tabular}{lcc}
\hline Problems & Mean & Standard deviation \\
\hline Lack of fund/finance & 1.09 & 0.28 \\
$\begin{array}{l}\text { Lack of support from government } \\
\text { Reluctance from people to participate in NGO }\end{array}$ & 1.11 & 0.32 \\
$\begin{array}{l}\text { programme } \\
\text { Incompetence of staff to handle climate }\end{array}$ & 1.66 & 0.59 \\
$\begin{array}{l}\text { change issue } \\
\begin{array}{l}\text { Climate change not within the NGO scope or } \\
\text { area of interest }\end{array}\end{array}$ & 1.83 & 0.71 \\
$\begin{array}{l}\text { Poor attitude of staff towards embracing new } \\
\text { issue like climate change }\end{array}$ & 1.80 & 0.80 \\
$\begin{array}{l}\text { Inaccessibility of some areas where climate } \\
\text { change information are needed }\end{array}$ & 1.66 & 0.58 \\
Low man power in the organisation & 1.80 & 0.64 \\
\hline
\end{tabular}

\section{Conclusion/ Recommendations}

Based on the findings of this study, it was concluded that although the NGOs are aware and knowledgeable about climate change (causes, effects, mitigation and adaptive measures to climate change), many are yet to include it in their program and as such yet to reach their clients /beneficiaries with information related to it. They may not encounter difficulties in creating awareness, sensitizing and educating the public about climate change and its effects as well as in helping government in enforcement of law that will mitigate climate change. NGOs programmes and mandates should be elaborate and flexible to accommodate emerging and topical issue (like climate change) as it concerns their clients (rural people). This will make their activities more relevant and important to their clients and the society at large

\section{References}

Egbule C.L (2012). Assessment of gender vulnerability and adaptation strategies to climate change impacts in Niger Delta Regions of Nigeria. A Ph.D Proposal Seminar paper, Department of Agricultural Extension, University of Nigeria, Nsukka.

Egbule C.L (2013). Gender vulnerability and adaptation strategies to climate change impacts on agriculture in Niger Delta Regions of Nigeria. A Ph.D research finding seminar paper. Department of Agricultural Extension, University of Nigeria, Nsukka.

Fraser, (2008) in Okoro, J.C (2012). Climate change information needs of rural farmers in Enugu State, Nigeria. Unpublished M.Sc. Project, Department of Agricultural Extension, University of Nigeria, Nsukka

http://know.climateofconcern.org/index.php?option=com content\&task=article\&id=143 Accessed 08/04/2014 
Muthukumara, M., Anil, M and Vijul, I (2008). Climate change adaptation and mitigation in development programmes: A Practical guide. Washington D.C: The World Bank.

Odjugo, P.A.O. (2009). Analysis of some effects of climate change in Nigeria. Journal of Nigeria Environment: Vol 5(1), 117-129.

Okoro, J.C (2012). Climate change information needs of rural farmers in Enugu State, Nigeria. Unpublished M.Sc. Project, Department of Agricultural Extension, University of Nigeria, Nsukka

Onyeme, N. F. and Iwuchukwu, J. C. (2012). Responsiveness of Extension workers to climate change in Anambra State Nigeria. Journal of Agricultural Extension 16(1) 88-102 Ibembe, J.D.B. (2007). "NGOs, Millennium Development Goals and Universal Primary

Igwe, U. (2006). The Role of Civil Society in Sustaining Reforms in Nigeria. A Paper Presented at the Global Civil Society Forum, Singapore. International Labour Office.

Intergovernmental panel on climate change (IPCC), (2007). Climate Change 2007: The Physical Science Basic Summary for policy makers. Contributions of working group1 to the Fourth Assessment Report of the IPCC.

PAMNET (2008). Humanizing States and Economies in Africa - A Rough Road for Civil Society Capacity Building. PAMNET Presentation - No. 002." Retrieved from: http://www.acbfpact.org/whatsnew/docs/State clvil Society Relations.pdf. Participatory Rural Appraisal'. Development and Change, Vol. 25, pp. 497- 526.

Stern, N. (2006). The Economics of Climate change: A review. Available at http://www.hmtreasury.gov.uk/independent reviews/stern-review economics climate change/stern review Report.cfm accessed 18/09/2011 World Bank Report (2001) “

World Faith Development Dialogue 1999: A Different World vision Transformational Development Indicators Field Guide. Washington:

www.articlesbase.com/science-articles/climate-change-a-global-challenge-a-globalconcern-3133806.html) Accessed 5/04/2014

www.chevron.com/global issues/climatechange/?utm-campaign=Africa:-corporate-iee www.eeaClimate Action Network Europe (CAN-E) accessed 5/04/2014 